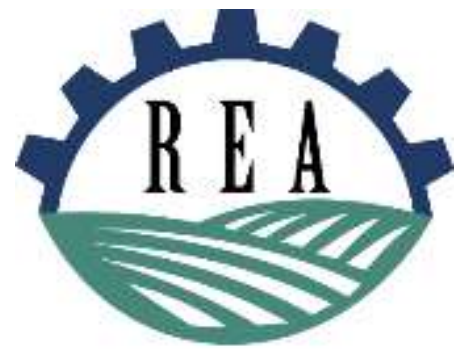

Revista de Economia e Agronegócio - REA ISSN impresso: 1679-1614

ISSN online: $2526-5539$

Vol. 16 | N. 1 | 2018

Lucas O. de Sousa ${ }^{1,2,5^{*}}$

Marcelo D. P. Ferreira 3

Luisa Vogt ${ }^{4}$

Marcus Mergenthaler 5

1 Universidade Federal de Mato

Grosso, Departamento de Zootecnia

e Extensão Rural, Cuiabá, Brasil

2 University of Hohenheim, Faculty of Agricultural Sciences, Stuttgart,

Alemanha

3 Universidade Federal de Goiás, Escola de Agronomia, Goiânia,

Brasil

4 Institute for Green Technology and Rural Development (i.green) - FHSWF, Soest, Alemanha.

5 South Westphalia University of Applied Sciences, Faculty of Agricultural Sciences, Soest, Alemanha.

* lucas.o.sousa@gmail.com

\section{CONTRACTS, SOCIAL NETWORK AND KNOWLEDGE DIFFUSION IN BRAZILIAN SUNFLOWER AGRI-FOOD CHAINS FOR POTENTIAL SUPPLY OF INNOVATIVE FOOD PROTEINS}

\begin{abstract}
The article analyzes the operation of sunflower agri-food chains in Brazil to understand possible ways to supply innovative sunflower food protein from Brazil. The findings from a multiple-case study approach show that the dynamic of operation of Brazilian sunflower agri-food chains are based on contracts, social network and knowledge diffusion. Although necessary, this governance arrangement has not been able to guarantee a sustainable longterm operation due to market, technological and supply chain management bottlenecks. Regional characteristics influence the level of transaction costs and the role of inputs suppliers in the chains' operation. The introduction of high value-added food protein products could raise the comparative advantage of sunflower in relation to competing crops, benefiting the chain operation. This article contributes to the understanding of the operation of agri-food chains focused on new or non-established crops, besides reinforcing the complementarity of transaction costs economics and social networks in explaining the functioning of social-economic systems.
\end{abstract}

Keywords: Agri-food chain; Brazil; Contracts; Sunflower; Trust.

\section{RESUMO}

O presente artigo analisa a dinâmica do funcionamento de cadeias agroindustriais de girassol no Brasil, em face de oportunidades relacionadas à produção de ingredientes alimentares proteicos funcionais à base de girassol. As análises baseadas em múltiplos estudos de casos indicam que essa dinâmica se fundamenta em contratos, redes sociais e difusão de conhecimento. Embora necessário, este arranjo de governança não tem sido capaz de garantir a operação sustentável a longo prazo dessas cadeias devido a limitações em termos de estrutura de mercado, tecnologia e gestão da cadeia de suprimentos. As especificidades regionais influenciam o nível dos custos de transação e o papel dos fornecedores de insumos na operação das cadeias. A produção no Brasil de proteínas alimentares de alto valor agregado à base de girassol poderia aumentar a vantagem comparativa do girassol em relação a culturas concorrentes, beneficiando o funcionamento da cadeia agroindustrial. Este artigo contribui para a compreensão do funcionamento de cadeias agroindustriais focadas em culturas novas ou não estabelecidas, além de reforçar a complementaridade das abordagens teóricas de economia dos custos e redes sociais na explicação do funcionamento dos sistemas socioeconômicos..

Palavras-chave: Cadeia agroindustrial; Brasil; Contratos; Girassol; Confiança.

JEL Code: Q13; Q16. 


\section{INTRODUCTION}

The replacement of animal protein by plant protein in human nutrition is seen as one possible mean for achieving a more sustainable food system in some contexts (AIKING, 2014). The driving forces for this change include (1) growth in population (2-billion over the next four decades) and in income, which is projected to lead to an increase in food demand globally, particularly for proteins (FAO, 2013), (2) limited capacity of meat supply to meet the expected protein demand, (3) the negative environmental effects associated with livestock production in some places (BONTEFRIEDHEIM, 2008), (4) concerns on animal welfare (VAINIO et al., 2016), and (5) potentially higher cost of animal protein compared to plant proteins (FROST \& SULLIVAN, 2010). This scenario has induced research and development in the public sector and in the food industry to identify and develop new sources and methods of plant protein production (GONZÁLEZ-PÉREZ; VEREIJKEN, 2007; WU et al., 2014).

Currently, soybean is the major source of plant protein ingredient in food (GONZÁLEZ-PÉREZ; VEREIJKEN, 2007). However, the growing use of genetically modified soybeans varieties has led the food industry in developed countries to search for alternative food proteins to soy (PICKARDT et al., 2015), as consumers often have a critical attitude towards genetically-modified food. In this regard, sunflower appears as a promising raw material for plant-based proteins (GONZÁLEZ-PÉREZ et al., 2002; GONZÁLEZ-PÉREZ; VEREIJKEN, 2007; PICKARDT et al., 2015; WEISZ; KAMMERER; CARLE, 2009). Within this context, the joint research project SunflowerProtein ${ }^{1}$ has developed and analyzed novel sunflower processing technologies. The focus is on the production of high quality and functional protein meal and concentrates for human consumption, instead of low value residues from the conventional deoiling process, usually destined for animal feed. SunflowerProtein evaluates the cultivation of sunflower and the possibility of the development of sunflower food protein ingredients in Brazil, given its prominent role in world agricultural supply.

The farming and processing of sunflower in Brazil date from the early 1900s. The planted area however has increased only from the late-1990s due to better cultivation and marketing conditions for sunflower oil (CASTRO et al., 2010; DALL'AGNOL; VIEIRA; LEITE, 2005). Nevertheless, the production of sunflower is concentrated, very limited, and oscillating. Three regions in the states of Mato Grosso, Goiás, Minas Gerais and Rio Grande do Sul concentrate more than $97 \%$ of the national sunflower production (CONAB, 2017; IBGE, 2017). Moreover, the sunflower cropping area (min. 47,800 ha in 2005 and max. 115,600 ha in 2014 ) corresponds to less than $1 \%$ of the world sunflower production area

\footnotetext{
1 Sustainable cultivation and novel processing of sunflower seeds for simultaneous production of sunflower oil, solid fuel and protein-rich food ingredients - an international cooperation research between German and Brazilian institutions, granted by the Federal Ministry of Education and Research (BMBF) of Germany and the National Counsel of Technological and Scientific Development (CNPq) of Brazil. 
(USDA, 2017) and less than 1\% of the national production area of maize and soybean. Notwithstanding, there is potential for the expansion of sunflower production in Brazil, due to the existence of agro-climatic conditions necessary to enable its cultivation, especially in grain producing areas (LAZZAROTTO; ROESSING; MELLO, 2005). Possible negative aspects of this expansion are currently difficult to be projected. Firstly, because it would take place in crop areas, minimizing the risk of deforestation. Secondly, due to the current small size of the sunflower producing area. Thus, even if the sunflower area increases by a factor of 10 , it will be still small in comparison with the cultivated area of soybean and maize.

Food innovations like the ones dealt within SunflowerProtein are normally led by the food industry and research institutes (WU et al., 2014). However, the implementation of such innovations, which rely on agricultural feedstocks specificities, depends on other agri-food chain actors with whom the innovator transacts (DU et al., 2016). This is due to the principles of interdependency, propagation, feedback, and synergy applied to systemic approaches, including agri-food chains (SILVA; SOUZA FILHO, 2007). Therefore, implementing a food industry innovation requires a holistic approach. In other words, it is necessary to understand the relationships among chain actors and the way the transactions take place. This justifies the consideration of formal and informal/relational governance structures for the analysis of agri-food chains (TRIENEKENS, 2011; TRIENEKENS; VAN DER VORST; VERDOUW, 2014).

Against this background, this article aims to analyze the dynamic of operation of sunflower agri-food chains in Brazil to understand possible ways to supply innovative sunflower food protein from Brazil. The following research question guides this article. How do formal and relational governance structures organize and coordinate the economic activities in agrifood chains of sunflower in Brazil? This article contributes to the understanding of the operation of agri-food chains focused on new or nonestablished crops. For policy makers, managers, and practitioners related to the food industry, the article highlights the need to consider relational governance forms, such as trust, and not only formal contracts to ensure the provision of feedstock and increase the chances of successful introduction of a food innovation. Theoretically, it reinforces the complementarity of transaction costs economics and social networks approaches in explaining the functioning of social-economic systems.

This introductory section is followed by the theoretical background section, which deals with transaction cost economics and the social network approach. Then, the methodology section describes the multiple-case study approach. After that, the section of analysis presents the main findings, followed by the discussion section. The final remarks section closes this article with the conclusions, recommendations, limitations and further research needs. 


\section{THEORETICAL BACKGROUND}

The dynamic of operation of a sunflower agri-food chain is related to the way in which the transactions between actors from different chain segments are organized. Therefore, analyzing this dynamic involves the analysis of the governance structures and the coordination mechanisms adopted by the actors to organize the chain's economic activities. Considering that social relations underpin economic transactions, this paper adopts two theoretical bases - transaction costs economics (TCE) and the social network approach.

TCE has been widely adopted in the agribusiness research, including in recent food systems analysis (e.g. WATANABE; ZYLBERSZTAJN, 2012). Due to this, the following description only highlights the main aspects of TCE based on Williamson $(1979,1985)$. According to this approach, the structures of governance are forms of managing exchanges and include spot markets, hybrid arrangements/contracts and vertical integration. TCE assumes that transactions are established under human behavioral attributes of bounded rationality and opportunism. Additionally, the appropriate governance structure depends on the characteristics of the transactions (asset specificity, uncertainty and frequency), which influence the level of transaction costs. The efficient governance structure is the one that minimizes the transaction costs and the risk of transaction failure. Transaction costs are defined as the "costs of running the economic system" (ARROW, 1969, p. 48), including costs of finding transaction partners, negotiating, monitoring and enforcing agreements.

Different forms of coordination mechanisms are associated with the governance structures. The coordination moves from market-managed form (price coordination) at the spot market, to increasing degrees of human-managed forms (vertical coordination). As the degrees of asset specificity, uncertainty and frequency increase, market-managed coordination via price increases transaction costs to a level at which it does not provide sufficient guarantees for the transactions' establishment. Thus, the actors move away from the spot market in direction to governance structures able to provide sufficient transaction safeguards (hybrid forms/contracts or vertical integration), minimizing the exchange costs and the risk of transaction failure. Under these structures, vertical (human-managed) coordination takes place.

Although TCE is an important theoretical approach to deal with the operation of agri-food chains, it is not sufficient to explain the coordination of economic activities. The reason is that social relations and not only human/transactions characteristics play a fundamental role in explaining how economic activities are organized. This is directly related to the concept of embeddedness, which refers to the fact that economic action is embedded in networks of social relations and is shaped by them (GRANOVETTER, 1985). Embeddedness affects the efficiency of formal governance structures (WILLIAMSON, 1993) and can be referred to as the highest level of social analysis, formed by informal institutions, customs, traditions, norms and religion, which are usually taken as given within 
TCE (WILLIAMSON, 2000). Uzzi (1997, p. 61) was even more specific in this regard by saying that "in an embedded logic of exchange, trust acts as the primary governance structure". This paper follows Uzzi's perspective to consider social networks, more specifically trust, as a possible structure of governance in agri-food chains of sunflower in Brazil.

Trust is defined as "the firm's [actor's] belief that another company [trading partner] will perform actions that will result in positive outcomes for the firm [actor], as well as not take unexpected actions that would result in negative outcomes for the firm [actor]" (ANDERSON; NARUS, 1990, p. 45). In the context of agri-food chains, trust is considered an informal or a relational governance mechanism, complementing the formal governance mechanisms of TCE (TRIENEKENS; VAN DER VORST; VERDOUW, 2014; ZHANG; ARAMYAN, 2009). Therefore, TCE and social networks (trust) are complementary approaches to deal with the analysis of the operation of sunflower agri-food chains.

Trust emerges from social relations or networks (FURLONG, 1996; GALASKIEWICZ, 2011) and depends on the duration of the relationship, successful previous experiences between parties and social and economic reputation (TRIENEKENS, 2011). Trust between market actors dampens the incidence of opportunistic behaviors and contractual hazard (MASUKU, 2009), decreasing the level of uncertainty surrounding the transaction. Consequently, it reduces the transaction costs and the risk of transaction failure, increasing the willingness of trading partners to invest in specific assets (BARNEY; HANSEN, 1994). Thus, the presence of trust may be seen as an incentive for potential trading partners to engage in exchange, favoring the repetition of future transactions. Since trust lessens the level of transaction costs, it affects the choice for the formal governance structure, in favor of less complex ones in terms of safeguards and monitoring mechanisms (FURLONG, 1996; GALASKIEWICZ, 2011; KEEFER; KNACK, 2005; TRIENEKENS, 2011). Moreover, trust is regarded as a self-enforcing mechanism for the fulfillment of actors' obligations, facilitating the transaction (KEEFER; KNACK, 2005; MASUKU, 2009). Empirical evidence positively relates trust with information exchange, cooperation and coordination (GALASKIEWICZ, 2011).

The above considerations on TCE and social network suggest that both formal and relational governance structures might be relevant means for the coordination of the economic activities in sunflower agri-food chains in Brazil. However, only the analysis of the cases can provide understanding on how the adopted governance structures contribute for the dynamic of operation of these chains. This means understanding "the way that institutions [formal and relational governance structures] provide incentives, sanctions, and information to promote particular types of behavior" (DORWARD; OMAMO, 2009, p. 86). 


\section{METHODOLOGY}

The article applies a casy study qualitative research approach. Case study is an appropriate method for researches dealing with the understanding of complex social-economic phenomena in its real-world context, over which the investigators have no control (YIN, 2014). This is the case of this article's aim of building an understanding of the dynamic of operation of agri-food chains of sunflower in Brazil. Multiple-case studies are preferable to a single-case study, once those provide greater explanatory power (MILES; HUBERMAN, 1984) as results can be triangulated.

Consequently, the findings obtained from multiple-case studies are considered more compelling and more robust (YIN, 2014). For this reason, a multiple-case embedded design was adopted.

In this framework, more than one case (unit of analysis) is analyzed and within each case different embedded units of analysis are considered (YIN, 2014). By the time of the data collection (2016), we identified four companies that were regularly producing sunflower edible oil in large scale in Brazil. This suggested the existence of four sunflower agri-food chains for this purpose - two in the state of Mato Grosso (MT)2, one covering the states of Goiás and Minas Gerais (GO/MG), and one in the state of Rio Grande do Sul (RS). The selection of the cases sought to cover all the three regions in order to capture the similarities and the specificities of the cases. Hence, three agri-food chains of sunflower were selected as case studies based on the availability of the processing companies' representatives to participate in this study - case $1(\mathrm{MT})$, case 2 (GO/MG) and case 3 (RS). Together these chains are responsible for the majority of the production and processing of sunflower in Brazil, which adds robustness to our findings. The embedded units of analysis considered in each case were the chain segments of input, farming, and processing. Sunflower is considered a non-established crop in the three cases, having the business focus on sunflower edible oil, with conventional sunflower meal as byproduct. The oil is sold to the food industry and final domestic consumers, while the meal is sold regionally as animal feed.

The first author conducted a field work for data collection in the four states, between April and August 2016. Semi-structured interviews held in Portuguese with 56 sunflower-related actors (Table 1) are the main source of information utilized in this article. Table 1 includes four actors from research institutions. Although they are not part of an embedded unit of analysis, their participation adds to the comprehension of the environment in which the agri-food chains of sunflower operate. The open-ended questions focused on the emergence process of these agri-food chains, seeking to understand what motivates the participation of actors from the three segments in the business of sunflower. This enabled the analysis of the dynamic of agri-food chain operation performed in this article. The

${ }^{2}$ This sunflower agri-food chain is the main one of the state of Mato Grosso, with twice the processing capacity (600 tons/day) of the other sunflower chain, which is not analyzed in this paper. 
duration of the interviews varied across the actors and the regions and the average lengths are shown in Table 1 . The recorded interviews amounted around 1450 minutes.

Table 1. Number of interviewees (A) and average length of the interviews in minutes (B)

\begin{tabular}{lcccccccr}
\hline & \multicolumn{2}{c}{ Case 1 } & \multicolumn{2}{c}{ Case 2 } & \multicolumn{2}{c}{ Case 3 } & \multicolumn{2}{c}{ National } \\
Chain segment & A & B & A & B & A & B & A & B \\
\hline Processing & 1 & 100 & 3 & 50 & 1 & 70 & & \\
Farming & 14 & 25 & 11 & 27 & 9 & 17 & & \\
Input & 7 & 44 & 5 & 39 & 4 & 23 & & \\
Research & 2 & 26 & & & & & 2 & 39 \\
\hline
\end{tabular}

Additionally, direct observation was another source of evidence to understand the dynamic of operation of the agri-food chains of sunflower in Brazil. Direct observation contributes to the comprehension of the social or environmental real-world conditions of the phenomena being studied, providing to the researcher in-depth involvement with the research problem (YIN, 2014). Direct observation was performed during site visits to farm supply retail stores, farms, and processing companies, besides in agricultural fairs (in Mato Grosso and Goiás) and farmers' activities (e.g. a farmers' field day in Mato Grosso). Furthermore, valuable occasions for direct observation resulted from the opportunity to closely accompany technical teams from the processing and input segments in their work of farmers' assistance.

The recorded interviews were transcribed using the transcription kit Olympus AS-2400, amounting around 240 pages. The qualitative data analysis software MAXQDA (version 11) assisted the process of interview transcripts analysis, enabling the development of a coding system to tag the interviews quotes. This facilitated the cross-case analysis, which was the analytical approach adopted in this article to identify and analyze common patterns in the operation of agri-food chains of sunflower in Brazil. The similarities in the dynamic of operation of the three sunflower agri-food chains would lead a within-case analysis to repetitive writings. Nevertheless, the main regional particularities of each case study were treated in the analysis.

\section{ANALYSIS}

\section{The operational environment}

The three sunflower agri-food chains analyzed in this study operate in an environment of high transaction costs. This fact is related to the high level of uncertainty associated with the low number of sunflower buyers and the unstable number of growers. When a farmer grows sunflower, he or 
she has very few buyers (sometimes only one) available in the region. This inhibits the entry of farmers in the sunflower business, as for competing crops such as maize they have several traders willing to buy it, which makes sunflower less competitive. Furthermore, the transportation cost of sunflower is usually more expensive ${ }^{3}$ than for other crops (soybean and maize), limiting the possibility of profitably selling sunflower to buyers from other regions. These facts make the farmer highly dependent on the (single) buyer.

However, asset specificity for farmers is relatively low. On the one side, the farmer, who already grows soybean and maize, can use the existing farm structure, machinery, and personnel to grow sunflower as an additional field crop. The direct investment (cost) to enter in the sunflower business refers basically to an adaptation in the combine header of maize (mainly) or soybean. This adaption has a low cost and can be executed in the farm. The knowledge on sunflower cropping can also be considered a specific asset, however as discussed further, this investment is assumed mainly by the processing company and/or input provider. Consequently, there are low entry/exit costs for farmers, making easier for them the decision to leave the crop in face of technical or commercial dissatisfactions.

On the side of the processing company, uncertainty is increased due to higher degree of asset specificity as compared to farmers. Given that the companies in the three cases operate with multi-seed plants, the assets specificity is more related to intangible assets. Thus, the main losses in case of closure of the sunflower business would not be related to the physical structure, which can continue to be used with other oilseeds. Rather, the losses would be related to the resources applied to establish a competitive positioning in the market of sunflower oil, which is a niche market within the edible vegetable oil sector in Brazil, led by soybean oil.

The unstable number of growers leads to high transaction costs on the side of the processing company. Difficulties to stabilize the supply of sunflower for the processors are related to several reasons, such as (1) the fact that farmers have other well-established crops to grow in the same crop season results in land use competition, especially with maize that ensures higher levels of stable liquidity due to higher number of buyers, (2) the fact that sunflower usually represents a small share of farmers' income, which is mainly derived from soybean and maize, (3) low farmers' exit costs, (4) low level of sunflower cropping knowledge observed among farmers, (5) a disease called "white mold", caused by the plant pathogenic fungus sclerotinia sclerotiorum, which besides affecting sunflower can generate losses for the subsequent soybean cultivation, and (6) low level of research and technology for sunflower in comparison with consolidated crops (soybean and maize), which can be seen by: the low number of researchers working on sunflower topics in Brazil, the low number of agrochemicals registered in the Ministry of Agriculture for the 
crop of sunflower, and the fact that most of the sunflower seeds available in Brazil are imported from Argentina or Bolivia and are not well-adapted to the Brazilian conditions.

This scenario generates interdependencies between farmers and the processor with different time horizons. In the short term (within a crop season), the farmer is highly dependent on the processing company after making a decision to grow sunflower, given the very limited number of sunflower buyers available. However, in the long term, the processing company depends more on the farmers to guarantee the supply of sunflower. Consequently, the power relations between these agents are balanced. In other words, the potentially high short-term market power of the buyer is reduced due to its long-term dependence in relation to its suppliers.

\section{Dynamic of chain operation}

The operational environment previously described has a direct influence in the dynamic of operation of sunflower agri-food chains in Brazil (Figure 1). This dynamic seeks to provide the incentives and safeguards for the engagement of actors in the sunflower agri-food chain. Within this dynamic, the organization of the economic activities involves contracts, social network, and knowledge diffusion under the coordination of the processing company.

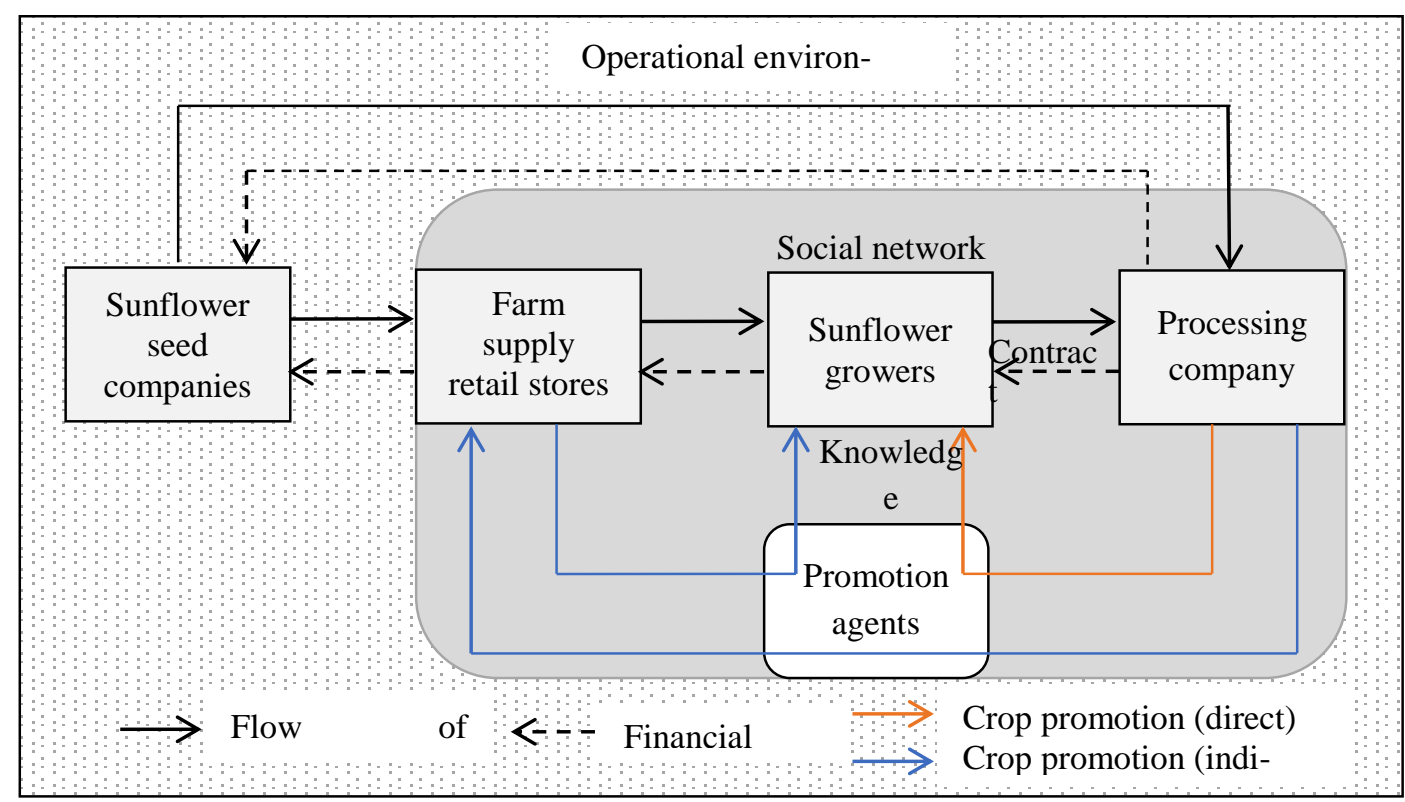

Figure 1. Dynamic of operation of agri-food chains of sunflower oil in Brazil $^{4}$

4 The lines connecting the sunflower seed segment to the processing company represents an inter-segment relation found in one of the Case RS. There, the processing company is also the sunflower seed distributor. 
"Crop promotion" is the key driver of this dynamic. Crop promotion puts together contractual relationship, social network, and knowledge diffusion with the goal of encouraging and assisting farmers in the growing of sunflower to be supplied to the processing company. The crop promotion is executed by promotion agents - technical teams of agronomists or agricultural technicians employed by the sunflower processor and/or by farm supply retail stores (FSRS). The crop promotion execution assumes mainly two approaches. The first one is the direct, in which the company's promotion agents are responsible for reaching and assisting farmers. The second one is the indirect, in which the crop promotion is done by a FSRS. In this case, the FSRS assumes the responsibility for promoting sunflower among farmers in its area of commercial coverage, linking them to the processing company. This represents a typical win-win relationship. The processing company benefits from the influence that a FSRS has over a large number of farmers, with whom it maintains close commercial and personal relationships. On the other hand, the FSRS benefits from the selling of inputs necessary for sunflower growing.

Contracts between the farmer and the processing company provide the formal transaction safeguards. The operational environment of the sunflower chains in Brazil requires vertical coordination mechanisms to guarantee their operation. In this regard, contracts are the formal governance structure adopted in the three cases. They specify in advance the conditions related to amount, price, payment and delivery of sunflower seeds, besides the penalties for noncompliance. The use of contracts reduces the uncertainties for farmers and for the processor. In the crop promotion approach, the contracts are offered to the farmer by the promotion agent.

The social network component is another essential factor for the sunflower chains operation in Brazil. Because sunflower is a non-established crop, its adoption is considerably influenced by personal relationships. This influence can come from a sunflower grower perceived as reliable and/or from a promotion agent, who is the person responsible for introducing the crop to farmers, showing technical, economic, and commercial aspects of the sunflower business. The participation of farmers in the chain linked to personal relationships decreases the risk of transaction failure, since the involvement of personal ties and trust diminishes the incentives for opportunistic actions. Farmers believe that the processing company will stick to the prices agreed in the formal contracts. At the same time the processing company believes that farmers will indeed deliver their sunflower seeds to the processing company and that farmers will make all necessary efforts to ensure that the agreed quantities will be delivered to the processing company (so that the processing company can fulfill the contracts with its customers). With these examples it becomes clear that the above given definition of "trust" plays a crucial role in the operation of the sunflower chain. Additionally, processing company's reputation is another aspect of the social network component. The restricted market structure reinforces the importance that farmers give to the good reputation of the buyer. Even previous negative experience of other 
farmers with other sunflower buyers (already out of the market) limits the interest of some farmers to enter or remain as suppliers in sunflower chains. This is not the case for well-established crops since farmers are more likely to continue in the market even after losses caused by trading partners' opportunistic behavior. Thus, the relevance of the social network component in terms of reliable personal relationships and good reputation suggests that trust constitutes the basic component of a relational governance structure in sunflower agri-food chains in Brazil. Trust is a necessary incentive for the transaction establishment in addition to formal contracts.

Knowledge diffusion is also a key component in the operation of the sunflower agri-food chains in Brazil. Although the provision of technical assistance is not exclusive to sunflower chains, it plays a major role in agrifood chains focused on new or non-established crops for which the cropping knowledge among farmers is still limited. In this context, the technical assistance (knowledge diffusion) is a determinant for the entrance and continuity of farmers in the agri-food chain. Moreover, different from well-established crops, as soybean and maize, the knowledge on sunflower is limited to a small number of actors and organizations in Brazil. For these reasons, the provision of technical assistance is part of the crop promotion approach. Besides being the mean for knowledge diffusion, the presence of the promotion agent in the farm for technical assistance during different periods within the sunflower season diminishes the incentives for moral hazard related to farmers' opportunistic behavior. Furthermore, it enables the processing company to adopt a flexible contractual posture. For instance, in case of non-provision of the agreed amount of sunflower seeds by a farmer, the processing company knows if this was related to some uncontrolled source (e.g. unsatisfactory outcomes due to seed's problems, diseases, drought, etc.) or to an opportunistic or negligent behavior. Thus, given the small size and the instability of the supply of sunflower mentioned earlier, the processing companies in the three cases have not applied contractual penalties when the noncompliance causes are not under control of the sunflower grower. This kind of behavior enhances the social network component in the dynamic of chain operation, as farmers see the company as a reasonable trustful partner.

\section{Regional specificities}

The level of crop promotion effort applied by the processing company and the role of farm supply retail stores (FSRS) in the dynamic of chain operation differs regionally (Table 2). The differences are mainly related to ownership of the processing companies, farmers' business structures, geographical distribution of sunflower production, and seasonality of crops, as described below for each one of the cases. 
Table 2. Crop promotion effort and role of FSRS at regional level

\begin{tabular}{lccc}
\hline & Case 1 & Case 2 & Case 3 \\
\hline $\begin{array}{l}\text { Crop promotion effort: direct approach } \\
\text { Crop promotion effort: indirect }\end{array}$ & Low & High & High \\
approach & Medium & High & Low \\
Role of FSRS in the agri-food chain & Cooperative & Strategic & Basic \\
\hline
\end{tabular}

The crop promotion effort applied in case 1 can be classified as low in terms of direct approach, and medium in terms of indirect approach. This agri-food chain emerged from an entrepreneurial initiative of farmers, who participate in the ownership of the processing company and provide part of its feedstock. Consequently, the need of searching for suppliers is reduced. Moreover, the concentration of sunflower growers in one municipality facilitates the interaction among them and the process of knowledge diffusion. Furthermore, the predominance of large-scale mechanized farms implies self-capacity for access to technical assistance.

This combination of factors results in lower transaction costs for this processing company in comparison to the ones in cases 2 and 3 . The crop promotion executed by the processing company, by means of the farmers in leadership positions, refers to the organization of activities for the exchange of experiences and information among farmers. Besides that, the company has a technical department in which one agricultural technician works with the goal of identifying more suitable techniques for the local growing of sunflower. The indirect approach of crop promotion has been coordinated by agents from the input sector. The focus is on promoting sunflower among farmers outside of the main sunflower-producing municipality, linking them to the processing company. The FSRS play a cooperative role. In general, the FSRS do not actively search for sunflower growers. Instead, they provide support for their clients who decide to grow sunflower. Moreover, the FSRS organize events related to the crop of sunflower generally in partnership with the processing company (e.g. farmers' field days).

In case 2, both approaches of crop promotion are highly utilized and focused on finding and supporting sunflower growers. This is related to the non-participation of farmers in the ownership of the company, which increases the instability of suppliers; the predominance of medium-sized farms that depends more on technical assistance; and the geographical dispersion of sunflower production over two states, which makes the direct approach insufficient. The company has a sunflower business unit in which two agronomists are responsible to coordinate the activities of sunflower crop promotion in partnership with farm supply retail stores. The FSRS play a strategic role for the operation of this agri-food chain. Once the adoption of sunflower in this region is highly influenced by farmers' relations with promotion agents from FSRS, the provision of sunflower for the processing company would be considerably lower without the participation of FSRS. 
In case 3, we found a high level of crop promotion by means of direct approach and a low one in terms of indirect approach. The need for crop promotion in this region is explained by the non-participation of farmers in the ownership of the processing company; the predominance of small and medium-sized farms; and, mainly, by the overlapping of sunflower and soybean seasons. This does not occur in the other two chains, where sunflower overlaps the maize and sorghum seasons. Since farmers normally use the whole arable land to grow soybean, the interest for sunflower in this region is considerably smaller. Besides processing sunflower, the company also operates as sunflower seed distributor. Thus, the crop promotion team employed by the company searches and supports sunflower growers, but also develops field trials with seeds. The goal is to identify more suitable cultivars for the region, especially in terms of shorter production cycle. This would minimize the overlapping period with the soybean season, contributing to a better fit of sunflower within the local agricultural production system. The small number of sunflower growers related to this chain makes the direct approach of crop promotion the main one. Nevertheless, a few partnerships with FSRS exist, as the company seeks to expand the production area of sunflower. Moreover, the indirect approach of crop promotion is a way to reduce the transaction costs for the company in the assistance of small sunflower suppliers. Even so, the FSRS currently play the basic role of providing inputs, except sunflower seed, to sunflower growers.

\section{Challenges for long-term sustainable operation}

The sunflower cases in Brazil suggest that the long-term efficient operation of agri-food chains focused on new or non-established crops is challenging. Limited market structure, land use competition with wellestablished crops (e.g. maize and soybean), and technological limitations (e.g. regarding plant breeding and control of pests and diseases) represent some of the barriers for the economic long-term sustainability of sunflower agri-food chains in Brazil. Consequently, the existing formal and relational governance structures associated with knowledge diffusion have not been sufficient to increase and stabilize the supply of sunflower in Brazil.

The instability in the sunflower supply in spite of the applied governance structures suggests further considerations. First, it points to the existence of a dynamic interplay of different governance structures that take place both simultaneously and over a certain time period, influencing production decisions and marketing of crops. The governance arrangement based on contracts, social network, and knowledge diffusion is more effective in the short-term, or within the crop season. This is especially true for the cases in which farmers do not participate in the control of the processing company. Although in the short-term (within a crop season) this governance arrangement is a necessary incentive for the farmer's decision to adopt sunflower, as well as a self-enforcing mechanism for fulfillment of the transaction, it has not been sufficient for 
ensuring the repetition of the transaction every year (as occurs with soybean and maize), due to the limitations of a non-established crop. Nevertheless, the governance arrangement adopted is decisive for the reentrance of former suppliers in the sunflower agri-food chain, once the market conditions seem attractive to them, which can be considered a long-term benefit of this arrangement.

\section{DISCUSSION}

Our analysis confirms the complementarity between transaction costs economics (TCE) (formal governance structures) and social network approach (relational governance structure) in relation to the sunflower agri-food chains in Brazil. This is consistent with other studies based on different agri-food chains from different countries (CHAGOMOKA; AFARI-SEFA; PITORO, 2014; FRITZ; FISCHER, 2007; GËRDOÇI et al., 2016; GËRDOÇI; SKRELI; IMAMI, 2016; MARTINO, 2010; TRIENEKENS, 2011; ZANDER; BESKE, 2014; ZHANG; ARAMYAN, 2009). An additional contribution of this article is the prominent role of knowledge diffusion and the elaboration of an integrated approach to explain the chain operation based on three key components - contracts, social network and knowledge diffusion. This approach appears especially appropriate for agri-food chains focused on new or non-established crops, as also observed in the case of the agri-food chain of castor bean in Brazil (WATANABE; ZYLBERSZTAJN, 2012). Furthermore, the analysis showed that the combinations of low exit cost for farmers and land use competition contribute to balance the supplier/buyer power relations due to different time horizons interdependencies. These interdependencies associated with the social network component dampen the risk of transaction failure.

The feedstock instability suggests a lack of supply chain management (SCM) in the operation of the agri-food chains of sunflower in Brazil. This is a fact also identified in other agri-food chains' studies (ANASTASIADIS; POOLE, 2015; BOURLAKIS; MAGLARAS; FOTOPOULOS, 2012). Furthermore, this evidences that, despite the presence of significant level collaboration and cooperation among chain actors (especially in the case in which farmers own the processing company), the establishment of well-managed agri-food supply chains is a complex endeavor that demands further business development investments.

One of the case studies points out that a close intertwining of farmers and processing company increases the stability and efficiency of an agri-food chain operation. Under this arrangement, the risk of feedstock shortage as well as transaction costs (e.g., associated with the searching and supporting of suppliers) are lower. This farmers' entrepreneurial initiative suggests the existence of enabling conditions (e.g. farming and managerial capacity, access to resources, collaboration and institutional environment) necessary for successful agri-food chains development (DONOVAN et al., 2015; KAHAN, 2012; LIE et al., 2012). 
Vertical integration would appear a strategy to circumvent the lack of supply chain management. However, recent studies have shown that vertical integration depends on several aspects such market power, inhouse feedstock costs, externally feedstock costs, trust, and capital constraint (DU et al., 2016; ZILBERMAN; LU; REARDON, 2017). From a processing company perspective, upstream integration appears to be a challenging task for several reasons. First, the main competition is for land and not for the product itself. Therefore, processing companies are not able to exert market power over farmers by producing some amount of sunflower in-house. Second, the main agricultural activities in the studied regions are soybean and maize. Thus, the purchase of feedstock such as sunflower from external sources appears to be cost effective over in-house production. As farmers normally cultivate two different crops in the same area per year, the land cost for sunflower production is smaller due to economy of scope. In addition, sunflower production in a large-scale basis would present high supervision costs, disabling vertical integration. Third, in a trusted environment, as sunflower production in Brazil appears to take place, the uncertainty regarding externally feedstock supply is addressed. This makes vertical integration less necessary. Fourth, if processing companies face capital constraint, they should invest in processing machinery instead of buying or renting agricultural land. The downstream vertical integration found in case 1 is somehow puzzling. Although the farmers own the processing company, both segments take decision separately. In addition, as the demand for feedstock increase, the processing company should rely on more external feedstock supply to deal with aspects highlighted above.

\section{FINAL REMARKS}

The economic transactions in the Brazilian sunflower agri-food chains are ruled by formal and relational governance structures and made possible through knowledge diffusion. Contracts, social network based on trust, and knowledge diffusion are necessary conditions for the operation of the agri-food chains of sunflower in Brazil. Nevertheless, the governance arrangement implemented so far has not been sufficient to guarantee a sustainable long-term operation of these chains, jeopardizing their expansion. In this sense, contracts, social network, and knowledge diffusion are the initial or short-term stimulus to the agricultural production, being subject to better market, technological, and supply chain management conditions.

Regional characteristics play an important role in the chains' dynamics. The agri-food chain wherein farmers with managerial capabilities participate in the ownership of the processing company presents a more consistent trustful relational environment, a stronger stimulus to knowledge diffusion, and less instability and risk of feedstock shortage as well as transaction costs. The higher the geographical dispersion of raw material suppliers and the processing company's scale of production, the greater the transaction costs and the strategic role of local farm supply 
retail stores for the chain operation. Finally, land use competition with the principal crop (soybean or maize) has a significant negative impact on the chain operation, resulting in smaller production area and higher transaction costs.

The introduction of high value-added food protein products could benefit the sunflower sector in Brazil. An expected higher overall profitability would raise the comparative advantage of sunflower in relation to competing crops, contributing to the growth and stability of sunflower production. Nevertheless, the analysis elaborated in this paper points to some relevant considerations for possible decision makers interested to invest in this business in Brazil.

First, crop promotion should be adopted while sunflower remains as a non-established crop. Second, efforts should be made to foster the research related to disease and pest control and plant breeding. Third, the adoption of SCM strategies could generate gains related to supply stability and efficiency in the agri-food chain operation. These strategies should be centered in providing to the chain actors a long-term and more sustainable perspective in order to reduce uncertainties and transaction costs. Finally, if the previous actions are not sufficient to minimize the risk of feedstock shortage and if the expected profits from this new market operation appear sufficiently high, decision makers should consider the adoption of long-term contracts (ideally with a price system that seeks to guarantee better profitability for sunflower in comparison with competing crops, especially maize) or even vertical integration. The total control of feedstock provision applies if asset specificities for sunflower food protein are considerably high and becomes a dominant entrance and exit barrier that increases substantially the transaction costs, hazards, and risks of transaction failure. Currently, vertical integration appears to be a limited strategy to sunflower processing companies in Brazil. Not surprisingly, vertical integration is not often observed in other annual oilseed chains in the country. However, incremental revenue related to high quality protein could change this scenario for sunflower agri-food chains. This incremental revenue would be greater in the context of market power regarding the new product, which may offset the transaction costs or costs related to vertical integration in the initial stage of the product life-cycle.

The findings of this paper reflect the realities of the agri-food chains of sunflower in Brazil analyzed in this study. Therefore, generalizations for other agri-food chains focused on new or non-established crops must be empirically validated in further researches. The more efficient operation of the agri-food chain led by farmers indicates that future research could look in more detail at this successful farmers' entrepreneurial initiative, which might contribute to policy implications in terms of agri-food chain development. Furthermore, although the understanding of the dynamic of chain operation is a necessary step before the introduction of food innovations that rely on agricultural feedstocks specificities, as sunflower protein food ingredients, further quantitative research approaches should deal with economic and logistics analysis to evaluate the conditions under 
which the introduction of these products would be profitable for the agrifood chain actors.

\section{ACKNOWLEDGEMENTS}

We thankfully acknowledge the doctorate scholarship awarded to the first author of this paper by the Brazilian Coordination for the Improvement of Higher Education Personnel (CAPES, BEX Number 9443/14-2). We are also thankful to the funders of the SunflowerProtein project - the German Federal Ministry of Education and Research (FKZ 031A281B) and the Brazilian Council for Scientific and Technological Development (CNPq 402022/2014-9). Our special thanks to Wolfgang Stauss for the overall project management. We are also extremely grateful to all individuals and companies that provided the information necessary for the development of this paper. Finally, we thank the anonymous referees for their valuable comments on earlier versions of this paper.

\section{REFERENCES}

AIKING, Harry. Protein production: planet, profit, plus people? The American Journal of Clinical Nutrition, [s.1.], v. 100, n. (suppl), p. 483S-489S, 2014. https:// doi.org/10.3945/ajcn.113.071209.

ANASTASIADIS, Foivos; POOLE, Nigel. Emergent supply chains in the agrifood sector: insights from a whole chain approach. Supply Chain Management: An International Journal, [s.1.], v. 20, n. 4, p. 353-368, 2015. https:// doi.org/10.1108/SCM-08-2014-0259

ANDERSON, James C.; NARUS, James A. A model of distributor firm and manufacturer firm working partnerships. Journal of Marketing, [s.1.], v. 54, n. 1, p. 42-58, 1990. Disponível em <http://www.jstor.org/stable/1252172>. Acesso em: 9 mar. 2017.

ARROW, Kenneth J. The organization of economic activity: Issues pertinent to the choice of market versus non-market allocation. The analysis and evaluation of public expenditures: The PPB System. Washington, D.C.: U.S. Government Printing Office, 1969. p. 47-64.

BARNEY, Jay A.; HANSEN, Mark H. Trustworthiness as a source of competitive advantage. Strategic Management Journal, [s.1.], v. 15, n. Supplement S1, p. 175-190, 1994. https:/ / doi.org/10.1002/smj.4250150912

BONTE-FRIEDHEIM, Christian. Globale Nahrungsmittelkrisen. Deutsche Gesellschaft für die Vereinten Nationen e.V. Disponível em: <http://www.dgvn.de/meldung/globale-nahrungsmittelkrisen/>. Acesso em: 8 jan. 2017.

BOURLAKIS, Michael; MAGLARAS, George; FOTOPOULOS, Christos. Creating a "best value supply chain"? Empirical evidence from the Greek food chain. International Journal of Logistics Management, [s.1.], v. 23, n. 3, p. 360-382, 2012. https:/ / doi.org/10.1108/09574091211289228 
CASTRO, C. et al. Sistema produtivo de girassol para a produção de biodiesel. In: CASTRO, Antônio Maria Gomes; LIMA, Suzana Maria Valle; SILVA, João Flávio Veloso (Org.). Complexo agroindustrial do biodiesel no Brasil: competitividade das cadeias produtivas de matérias-primas. Brasília: Embrapa Agroenergia, 2010. p. 376-420, cap. 9.

CHAGOMOKA, Takemore; AFARI-SEFA, Victor; PITORO, Raul. Value chain analysis of traditional vegetables from Malawi and Mozambique. International Food and Agribusiness Management Review, [s.1.], v. 17, n. 4, p. 59-86, 2014.

Disponível em: <https://www.ifama.org/resources/Documents/v17i4/ChagomokaSefa-Pitoro.pdf>. Acesso em: 12 mar. 2017.

COMPANHIA NACIONAL DE ABASTECIMENTO - CONAB. Acompanhamento da safra brasileira de grãos, v. 4 Safra 2016/17. Brasília: CONAB, 2017. Disponível em: <http://www.conab.gov.br/OlalaCMS/uploads/arquivos/17_02_09_09_ 00_14_boletim_graos_fevereiro_2017.pdf >. Acesso em: 20 fev. 2017.

DALL'AGNOL, Amélio; VIEIRA, Osvaldo Vieira; LEITE, Regina Maria Villas Bôas de Campos. Origem e histórico do girassol. In: LEITE, Regina Maria Villas Bôas de Campos; BRIGHENTI, Alexandre Magno; CASTRO, César (Org.). Girassol no Brasil. Londrina: Embrapa Soja, 2005. p. 1-14. cap. 1.

DONOVAN, J. et al. Guides for value chain development: A comparative review. Journal of Agribusiness in Developing and Emerging Economies, [s.1.], v. 5, n. 1, p. 2-23, 2015. https:// doi.org/10.1108/JADEE-07-2013-0025

DORWARD, Andrew R.; OMAMO, S. Were; A Framework for Analyzing Institutions. In: KIRSTEN, J. F. et al. (Org.). Institutional Economics Perspectives on African Agricultural Development. Washington, D.C.: IFPRI, 2009. p. 75-110. cap. 3.

DU, X. et al. Economics of agricultural supply chain design: A portfolio selection approach. American Journal of Agricultural Economics, [s.l.], v. 98, n. 5, p. 1377-1388, 2016. https:// doi.org/10.1093/ajae/aaw074

FOOD AND AGRICULTURAL ORGANIZATION - FAO. Fao Statistical Yearbook 2013: World food and agriculture. Rome, Italy: FAO, 2013. Disponível em: <http://www.fao.org/docrep/018/i3107e/i3107e.PDF>. Acesso em: 8 jan. 2017.

FRITZ, Melanie; FISCHER, Christian. The role of trust in European food chains: Theory and empirical findings. International Food and Agribusiness Management Review, v. 10, n. 2, p. 141-161, 2007. Disponível em: <https://www.ifama.org/resources/Documents/v10i2/FritzFischer.pdf> Acesso em: 12 abr. 2017.

FROST \& SULLIVAN. Trends and Opportunities in the European Protein Ingredients $\quad$ Market. 2010. Disponível em: <http://www.frost.com/sublib/display-report.do?id=M5FE-01-00-00-00> Acesso em: 8 jan. 2017. 
FURLONG, Dominique. The Conceptualization of "Trust" in Economic Thought. , IDS working papers no 35. Brighton, U.K.: 1996. Disponível em: <http://www.ids.ac.uk/publication/the-conceptualization-of-trust-ineconomic-thought>. Acesso em: 11 dez. 2016.

GALASKIEWICZ, Joseph. Studying supply chains from a social network perspective. Journal of Supply Chain Management, [s.1.], v. 47, n. 1, p. 4-8, 2011. doi:10.1111/j.1745-493X.2010.03209.x

GËRDOÇI, B. et al. Relational Ties and Transaction Costs - The Moderating Role of Uncertainty. International Food and Agribusiness Management Review, [s.1.], v. 19, n. 2, p. 189-206, 2016. Disponível em: <https:/ / www.ifama.org/resources/Documents/v19i2/920140199.pdf>. Acesso em: 12 abr. 2017.

GËRDOÇI, Blendi; SKRELI, Engjell; IMAMI, Drini. Determinants of sustainable relationships in the Albanian apple production sector. International Journal on Food System Dynamics, Bonn, v. 7, n. 1, p. 50-65, 2016. http:/ / dx.doi.org/10.18461/ijfsd.v7i1.715

GONZÁLEZ-PÉREZ, S. et al. Isolation and characterization of undenatured chlorogenic acid free sunflower (Helianthus annuus) proteins. Journal of Agricultural and Food Chemistry, [s.1.], v. 50, n. 6, p. 17131719, 2002. DOI: $10.1021 /$ jf011245d

GONZÁLEZ-PÉREZ, Sergio; VEREIJKEN, Johan M. Sunflower proteins: overview of their physicochemical, structural and functional properties. Journal of the Science of Food and Agriculture, v. 87, n. 12, p. 2173-2191, 2007. DOI: $10.1002 /$ jsfa.2971

GRANOVETTER, Mark. Economic Action and Social Structure: The Problem of Embeddedness. American Journal of Sociology, [s.1.], v. 91, n. 3 (Nov., 1985), p. 481-510, 1985.

INSTITUTO BRASILEIRO DE GEOGRAFIA E ESTATÍSTICA - IBGE. Produção Agrícola Municipal - 2015. Disponível em: <https://sidra.ibge.gov.br/pesquisa/pam/tabelas>. Acesso em: 7 jan. 2017.

KAHAN, David. Entrepreneurship in Farming. FAO, Roma, 2012. Disponível em: <http://www.fao.org/uploads/media/5EntrepreneurshipInternLores.pdf>. Acesso em: 12 abr. 2017.

KEEFER, Philip; KNACK, Stephen. Social Capital, Social Norms and the New Institutional Economics. In: MENARD, Claude; SHIRLEY, Mary M. (Org.). Handbook of New Institutional Economics. [S.1.]: Springer, 2005. p. 701-726. cap. 27.

LAZZAROTTO, Joelsio José; ROESSING, Antônio Carlos; MELLO, Heveraldo Camargo. O agronegócio do girassol no mundo e no Brasil. In: LEITE, Regina Maria Villas Bôas de Campos; BRIGHENTI, Alexandre Magno; CASTRO, César (Org.). Girassol no Brasil. Londrina: Embrapa Soja, 2005. p. 15-42. cap. 2. 
LIE, H. et al. Improving smallholder livelihoods through local value chain development: a case study of goat milk yogurt in Tanzania Improving smallholder livelihoods through local value chain development: a case study of goat milk yogurt in Tanzania. International Food and Agribusiness Management Review, [s.1.] v. 15, n. 3, p. 55-86, 2012. Disponível em: <https://www.ifama.org/resources/Documents/v15i3/Lie-RichJervell.pdf>. Acesso em: 12 abr. 2017.

MARTINO, Gaetano. Trust, Contracting, and Adaptation in Agri-Food Hybrid Structures. International Journal of Food System Dynamics, Bonn, v. 1, n. 4, p. 305-317, 2010. Disponível em: <http://centmapress.ilb.unibonn.de/ojs/index.php/fsd/article/view/143>. Acesso em: 14 abr. 2017.

MASUKU, Micah B. The role of trust in contract enforcement: An analysis of smallholder farmers and sugar millers in Swaziland. In: KIRSTEN, J. F. et al. (Org.). Institutional Economics Perspectives on African Agricultural Development. Washington, D.C.: IFPRI, 2009. p. 185-199. cap. 6.

MILES, Matthew. B.; HUBERMAN, A. Michael. Qualitative Data Analysis: A Sourcebook of New Methods. Thousand Oaks, CA: Sage Publications, 1984.

PICKARDT, C. et al. Pilot plant preparation of light-coloured protein isolates from de-oiled sunflower (Helianthus annuus L.) press cake by mild-acidic protein extraction and polyphenol adsorption. Food $\begin{array}{llllll}\text { Hydrocolloids, } & \text { [s.1.], } & \text { v. } & 44, & \text { p. 208-219, }\end{array}$ http:/ / dx.doi.org/10.1016/j.foodhyd.2014.09.020

SILVA, Carlos A. da; SOUZA FILHO, Hildo M. Guidelines for rapid appraisals of agrifood chain performance in developing countries. Rome, Italy: FAO, 2007. Disponível em: <http://www.fao.org/3/a-a1475e.pdf>. Acesso em: 11 jan. 2017.

TRIENEKENS, Jacques H. Agricultural value chains in developing countries a framework for analysis. International Food and Agribusiness Management Review, [s.1.], v. 14, n. 2, p. 51-82, 2011. Disponível em: <https://www.ifama.org/resources/Documents/v14i2/Trienekens.pdf>. Acesso em: 11 jan. 2017.

TRIENEKENS, Jacques H.; VAN DER VORST, J. G. A. J.; VERDOUW, C. N. Global Food Supply Chains. In: VAN ALFEN, Neal K. (Org.). Encyclopedia of Agriculture and Food Systems. [s.1.]: Elsevier Inc., 2014. 3 v. p. 499-517.

UNITED STATES DEPARTMENT OF AGRICULTURE - USDA. Production, supply and distribution / PSD Online / Custom Query. Disponível em:

<https:/ /apps.fas.usda.gov/psdonline/app/index.html\#/app/advQuery >. Acesso em: 7 jan. 2017.

UZZI, Brian. Social Structure and Competition in Interfirm Networks: The Paradox of Embeddedness. Administrative Science Quarterly, [s.1.], v. 42, n. 1, p. 35-67, 1997. Disponível em: <www.jstor.org/stable/2393808>. Acesso em: 11 jan. 2017. 
VAINIO, A. et al. From beef to beans: Eating motives and the replacement of animal proteins with plant proteins among Finnish consumers. Appetite, [s.l.], v. 106, p. 2016. http:/ / dx.doi.org/10.1016/j.appet.2016.03.002

WATANABE, Kassia; ZYLBERSZTAJN, Decio. Building Supply Systems from Scratch: The Case of the Castor Bean for Biodiesel Chain in Minas Gerais, Brazil. International Journal on Food System Dynamics, Bonn, v. 3, n. 2, p. 185-198, 2012. Disponível em: <http://centmapress.ilb.unibonn.de/ojs/index.php/fsd/article/view/327>. Acesso em: 14 abr. 2017.

WEISZ, Georg M.; KAMMERER, Dietmar R.; CARLE, Reinhold. Identification and quantification of phenolic compounds from sunflower (Helianthus annuus L.) kernels and shells by HPLC-DAD/ESI-MSn. Food

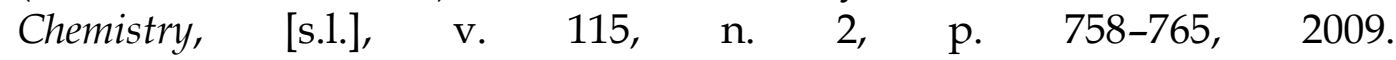
https:// doi.org/10.1016/j.foodchem.2008.12.074

WILLIAMSON, Oliver E. Calculativeness, Trust, and Economic Organization. Journal of Law and Economics, [s.1.], v. 36, n. 1, p. 453-486, 1993.

WILLIAMSON, Oliver E. The economic institutions of capitalism. New York: Free Press, 1985.

WILLIAMSON, Oliver E. The New Institutional Economics: Taking Stock, Looking Ahead. Journal of Economic Literature, [s.1.], v. 38, n. 3, p. 595-613, 2000. Disponível em: <http://www.jstor.org/stable/2565421>. Acesso em: 11 jan. 2017.

WILLIAMSON, Oliver E. Transaction-Cost Economics: The Governance of Contractual Relations. Journal of Law and Economics, [s.1.], v. 22, n. 2, p. 233261, 1979. Disponível em: <http://www.jstor.org/stable/725118>. Acesso em: 11 jan. 2017.

WU, G. et al. Production and supply of high-quality food protein for human consumption: Sustainability, challenges, and innovations. Annals of the New York Academy of Sciences, New York, v. 1321, n. 1, p. 1-19, 2014.

YIN, Robert K. Case Study Research Design and Methods. 5th. ed. Thousand Oaks, CA: Sage Publications, 2014.

ZANDER, Katrin; BESKE, Philip. Happy Growers! Relationship Quality in the German Organic Apple Chain. International Food $\mathcal{E}$ Agribusiness Management Review, [s.1.], v. 17, n. 3, p. 205-223, 2014. Disponível em: https:// www.ifama.org/resources/Documents/v17i3/Zander-Beske.pdf. Acesso em: 15 abr. 2017.

ZHANG, Xiaoyong; ARAMYAN, Lusine H. A conceptual framework for supply chain governance: An application to agri-food chains in China. China Agricultural Economic Review, [s.1.], v. 1, n. 2, p. 136-154, 2009. Disponível em: https://doi.org/10.1108/17561370910927408

ZILBERMAN, David; LU, Liang; REARDON, T. Innovation-induced food supply chain design. Food Policy, [s.1.], 2017. https:// doi.org/10.1016/j.foodpol.2017.03.010 